\title{
Magnetic susceptibility mapping: applications for the Meguma Group, central Nova Scotia
}

\author{
M.S. King \\ 20 Armshore Drive, Halifox, Nova Scotia B3N IM5, Canada \\ Date Received January 15, 1996 \\ Date Accepted July 7, 1997
}

\begin{abstract}
An extensive magnetic susceptibility mapping program was undertaken in conjunction with re-processing and enhancement of aeromagnetic data over the Meguma Group of Nova Scotia. The ground follow-up consisted of several thousand in situ magnetic susceptibility measurements collected in conjunction with a detailed geological mapping program designed to identify the sources of newly resolved aeromagnetic anomalies. Analysis of the susceptibility data and magnetic mineralogy identified a strong correlation between general magnetic character and stratigraphy. This correlation can be confidently demonstrated at the member level (e.g., Glen Brook unit), however, more detailed relationship, correspond to lithological variations within a particular unit. For example, slate packages within the Steves Road. unit have a mean susceptibility of $0.41( \pm 0.09) \times 10^{-3} \mathrm{SI}$ compared to $0.11( \pm 0.09) \times 10^{-3} \mathrm{SI}$, for the predominant meta-sandstone strata. Other examples include various lithologies in the Goldenville Halifax Transition zone Upper Beds unit, which consists of silty slate ( $k_{\text {ave }}=0.58 \times 10^{-3} \mathrm{SI}$ ), Mnrich silt beds $\left(k_{a v e}=1.02 \times 10^{-3} \mathrm{SI}\right)$, and tightly folded sulphide rich sand beds $\left(k_{a v e}=1.68 \times 10^{-3} \mathrm{SI}\right)$. In situ susceptibility data is also an indicator of sulphide content in the slates of the Halifax Formation including pyrrhotite and to a lesser degree, pyrite. The susceptibility readings also appeared to indicate anisotropy of magnetic susceptibility (AMS) in the slates where pyrrhotite grains were oriented parallel to well developed cleavage. Within the Goldenville Formation, magnetic susceptibility measurements frequently provide the only indication of lithological variations and hence facilitate the mapping of the monotonous metasandstone packages. Marker horizons can also be traced in a similar fashion.
\end{abstract}

On a réalisé un vaste programme de cartographie de la susceptibilité magnétique, conjointement avec un retraitement et un enrichissement des données aéromagnétiques, au-dessus du groupe de Meguma en NouvelleÉcosse. Le suivi au sol a comporté plusieurs milliers de prélèvements de mesures de la susceptibilité magnétique sur place, conjointement avec un programme de cartographie géologique détaillé visant à déceler les sources des anomalies magnétiques récemment résolues. L'analyse des données de susceptibilité et des valeurs minéralogiques magnétiques a fait ressortir une corrélation prononcée entre la stratigraphie et le caractère magnétique général des lieux. On peut facilement montrer cette corrélation au niveau du membre (p. ex. I'unité Glen Brook), mais les rapports plus détaillés correspondent à des variations lithologiques à l'intérieur d'une unité particulière. Les ensembles d'ardoise à l'intérieur de l'unité du chemin Steve's, par exemple, affichent une susceptibilité moyenne de $0,41(+0,09) \times 10^{-3}$ SI comparativement à $0,11(+0,09) \times 10^{-3}$ SI dans le cas des strates prédominantes de métagrès. On a d'autres exemples de cette corrélation avec les diverses structures lithologiques à l'intérieur de l'unité Upper Beds de la zone de transition entre Goldenville et Halifax, qui est constituée d'ardoise limoneuse ( $k_{\text {ave }}=0,58 \times 10^{-3} \mathrm{SI}$ ), ainsi qu'avec les couches de limon riches en $\mathrm{Mn}\left(\mathrm{k}_{\mathrm{ave}}=1,02 \times 10^{-3} \mathrm{SI}\right)$ et les couches de sable riches en sulfures à plis fermés $\left(\mathrm{K}_{\mathrm{ave}}=1,68 \times 10^{-3} \mathrm{SI}\right)$. Les données de susceptibilité in situ constituent en outre un indicateur de la teneur en sulfure des ardoises de la Formation d'Halifax, notamment la pyrrhotine et, dans une mesure moindre, la pyrite. Les relevés de susceptibilité semblent par ailleurs révéler une anisotropie de la susceptibilité magnétique (ASM) dans les ardoises où les grains de pyrrhotine étaient orientés dans une direction parallèle à une schistosité bien établie. A l'intérieur de la Formation de Goldenville, les mesures de la susceptibilité magnétique ne constituent fréquemment que la seule indication de variations lithologiques; elles facilitent par conséquent la cartographie des ensembles de métagrès monotones. On peut également délimiter les horizons repères de la même façon.

[Traduit par la rédaction]

\section{INTRODUCTION}

High resolution aeromagnetic data over the Meguma terrane of Nova Scotia (Fig. 1) reveal numerous narrow, linear aeromagnetic anomalies (Fig. 2) that parallel regional stratigraphy, and presumably reflect stratigraphic variations in magnetic character. Ball (1974) used magnetic characteristics such as susceptibility and total field measurements to study contact metamorphism in metasedimentary rocks of the Meguma Group. He found variations in the response to be caused by stratigraphically controlled ferrimagnetic minerals, thereby establishing a qualitative correlation between Meguma Group stratigraphy and magnetic character. In order to define more quantitative relationships, a field susceptibility mapping program was designed to evaluate correlations between fundamental magnetic parameters (i.e., susceptibility) and recently de- 


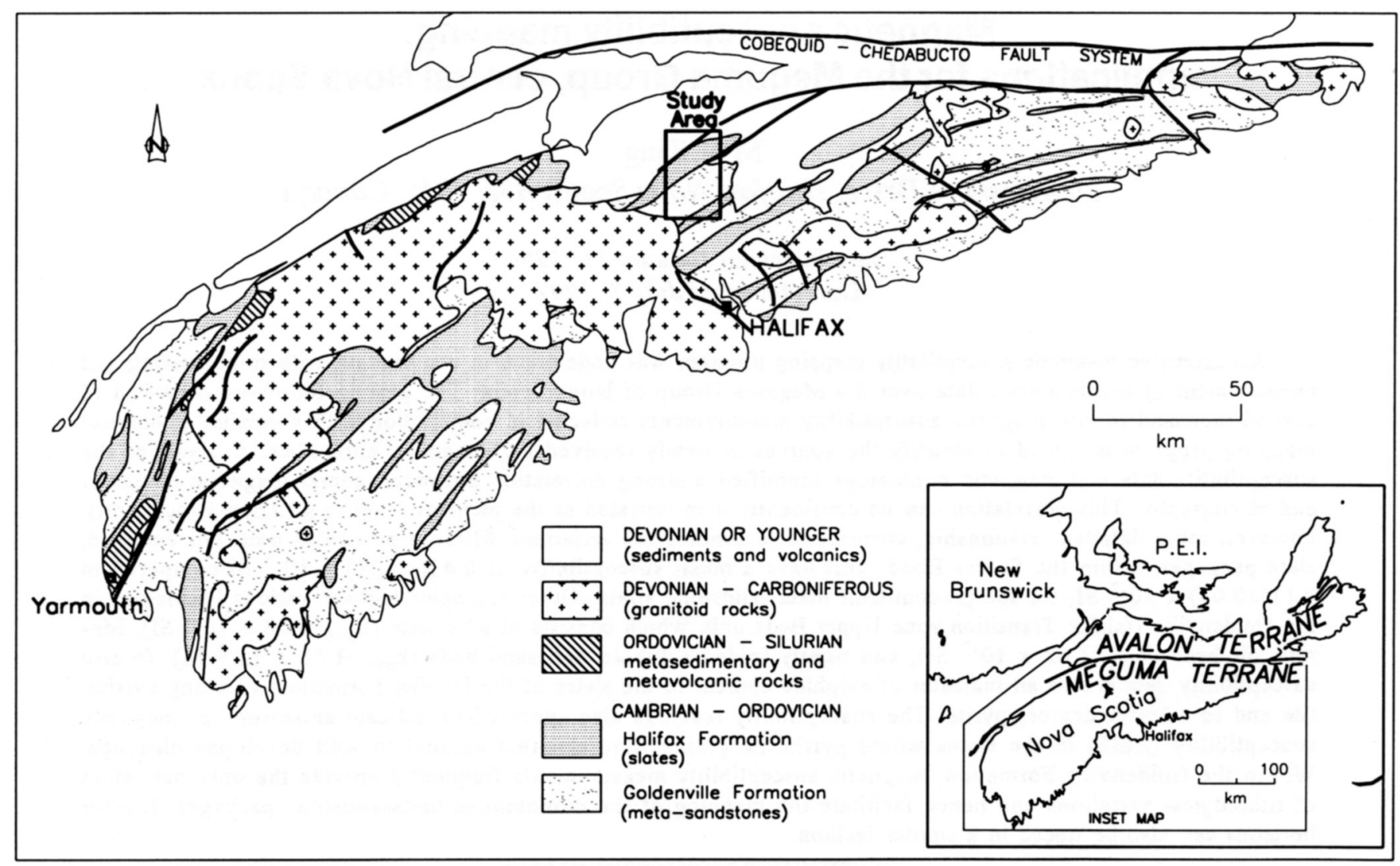

Fig. 1. Simplified geological map of southeastern Nova Scotia showing the location of the study area.

fined stratigraphy (e.g., Horne, 1993, 1995; Ryan, 1994). This quantitative information provides a degree of control which will allow a more broad and accurate application of ground and aeromagnetic data for mapping, environmental, and exploration programs.

Although aeromagnetic response is affected by numerous physical phenomena (e.g., type, quantity, and distribution of ferrimagnetic minerals), the relationship may be simplified to that of the induced magnetization generated by an applied magnetic field. The intensity of the magnetic response, $\mathrm{J}_{\mathrm{I}}$ due to a magnetizing force $\mathrm{H}$ is expressed by:

$$
\mathrm{J}_{\mathrm{I}}=\mathbf{k H} \pm \mathrm{J}_{\mathbf{R}}
$$

Where $\mathbf{k}$ is the magnetic susceptibility and $J_{R}$ is the intensity of remanent magnetization (Nagata, 1961). Henc, magnetic susceptibility $(k)$ is defined as the ratio of magnetization to the magnetizing force or the degree to which a substance can be magnetized. In SI units, $J_{I}, H$, and $J_{R}$ are measured in Amperes per meter $(\mathrm{A} / \mathrm{m})$, and hence $k$ is dimensionless. Assuming that a qualitative relationship exists between the magnetic response and stratigraphy as demonstrated by Ball (1974) and King (1994b), it follows from Eq. 1, that there must also exist a relationship between magnetic susceptibility and stratigraphy. Other rationale for this correlation include the close relationship between stratigraphic attributes, such as grain size and mineralogy, and the bulk susceptibility of a rock (Nagata, 1961).
Analysis of in situ susceptibility measurements has shown excellent correlation between magnetic susceptibility and stratigraphy and numerous other geological factors. Susceptibility mapping enhances geological investigations by providing semi-quantitative characteristics for strata that may otherwise appear non-distinct (King, 1994a). Bulk susceptibility, as defined by the arithmetic mean, is also proportional to the amount of sulfide minerals in a slate/argillite outcrop where pyrrhotite $\left(\mathrm{Fe}_{7} \mathrm{~S}_{8}\right)$, has been recognized. Within the Halifax Formation, where pyrite and pyrrhotite are commonly linked to "acid mine drainage", magnetic susceptibility provides a non-intrusive method for detecting problematic horizons. Magnetic minerals are also sensitive indicators of depositional and metamorphic conditions (Borradaile and Sarvas, 1990); therefore susceptibility data, through mineralogical correlations, may also assist in understanding depositional regimes and metamorphic histories. Susceptibility measurements have also been used to define in anisotropy of magnetic susceptibility (AMS) which, when present, is a useful element for structural analysis and detailed geophysical interpretations.

Analysis of several thousand in situ magnetic susceptibility readings has demonstrated that magnetic properties are correlatable with stratigraphic variations at both local and regional scales. Magnetic susceptibility data also demonstrate a quantitative relationship between the amount of sulphide minerals and the magnetic susceptibility in slate and argillite units in the Halifax Formation. 


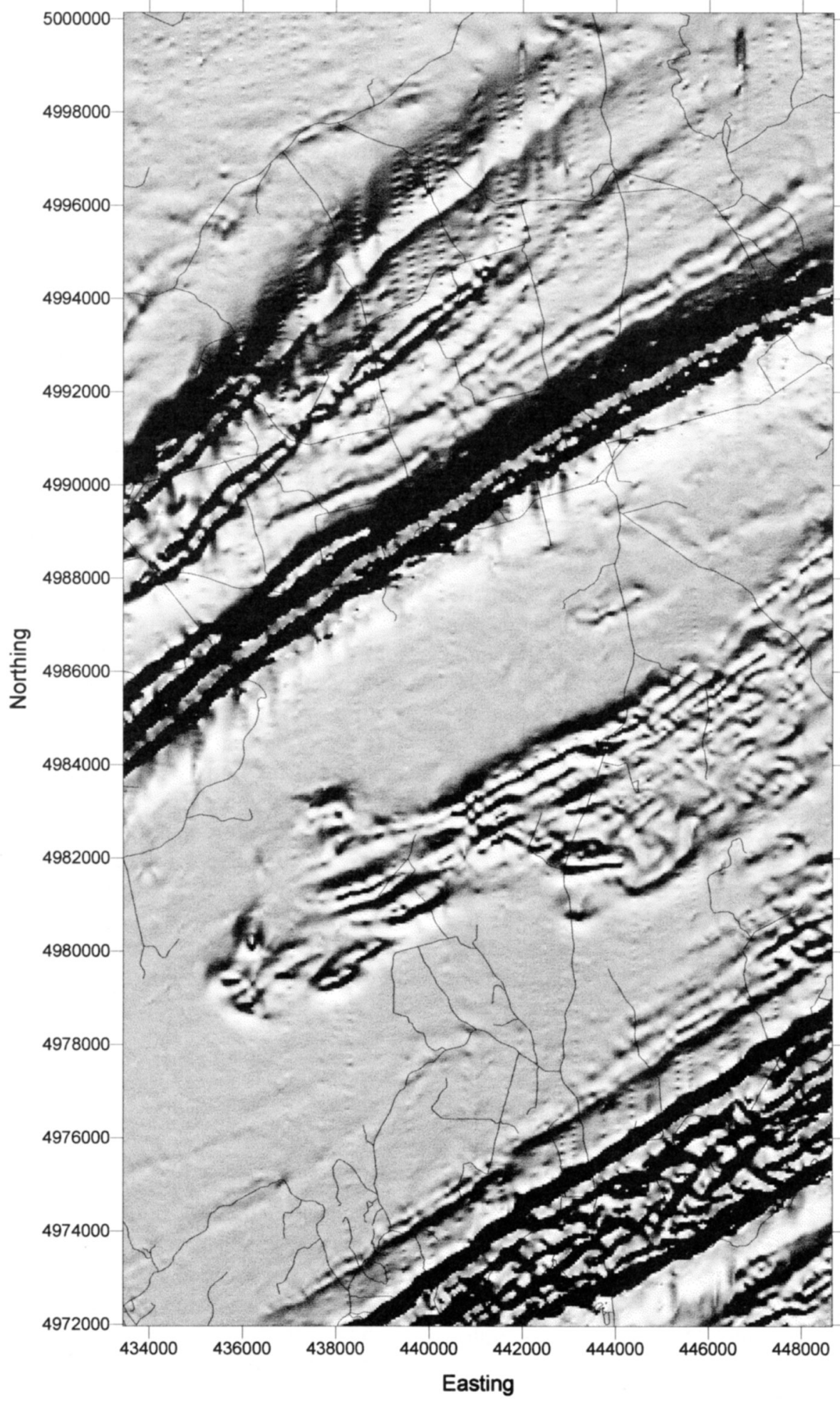

\section{Scale}

Fig. 2. Shaded relief enhanced aeromagnetic map with the study area shown. The data, acquired by the Geological Survey of Canada during the "Halifax Survey", was de-corrugated to remove levelling errors and the second vertical derivative was calculated. Illumination parameters: inclination $=45^{\circ}$, declination $0^{\circ}$. 


\section{General geology}

The Meguma terrane represents the easternmost portion of the Canadian Appalachian Orogen and comprises the majority of southern Nova Scotia (Fig. 1). Cambro-Ordovician metasedimentary rocks in the Meguma Group underwent regional compression during the mid-Devonian Acadian Orogeny, resulting in the development of asymmetric, eastwest and northeast-southwest trending, non-cylindrical, open to tight folds with associated slatey and/or spaced axial planar cleavage. The metamorphic grade is greenshist to amphibolite facies with local contact metamorphic aureoles developed near granitoid intrusions (Taylor and Schiller, 1966). The Meguma Group was intruded by numerous late Devonian granitic plutons. Marine and terrigenous Carboniferous sedimentary rocks unconformably overlie the older rocks.

The Meguma Group is a turbidite succession and is typically divided into the metasandstone-dominated Goldenville Formation and overlying slate-siltstone-argillite-dominated Halifax Formation (e.g., Schenk, 1970; Keppie, 1979). The Goldenville Formation consists of thickly to thinly bedded metasandstone interbedded with siltstone and variable amounts of slate. Recent work (O'Brien, 1988; Waldron, 1991; Ryan, 1994; Horne, 1993, 1995) identified further stratigraphic subdivisions on a local scale. Most notable are the transition zone between the Halifax and Goldenville formations and divisions within the Halifax Formation. Several authors (e.g., Graves and Zentilli, 1988; O'Brien, 1988; Waldron, 1991; Ryan, 1994) identified distinctive lithologic units occurring at the boundary between the Halifax and Goldenville formations and informally referred to this sequence as the Goldenville-Halifax Transition zone (GHT). The basal Halifax Formation comprises graphitic, sulphide-rich slate deposited in anoxic conditions, which in turn is overlain by pale green to grey, slate and metasiltstones which have experienced greater oxidation (Schenk, 1991).

\section{Detailed geology}

Within the study area, the Goldenville and Halifax formations have been subdivided into several units and the Goldenville-Halifax Transition (GHT) zone has also been identified as a mappable sequence (Fig. 3). The overlying Carboniferous strata were not part of the detailed mapping program but outcrops of Carboniferous strata were sampled where encountered.

The Goldenville Formation has been informally divided into metasandstone (undivided Goldenville Formation) and the Steves Road unit. The Steves Road unit occurs in the uppermost section of the Goldenville Formation and is characterized by slate interbeds and well developed cross-bedding in the dominant metasandstone beds (Ryan, 1994).

Ryan (1994) identified and mapped the Goldenville-Halifax Transition zone in the study area, and his stratigraphic definitions of the GHT are used in this paper. Within the Uniacke syncline, the Goldenville-Halifax Transition zone is divided locally into two map units. Ryan (1994) characterized the
Lower Beds of the transition zone by the presence of equal amounts of argillite, silty slate and thin meta-sandstone. He noted that the sandy beds have well developed spaced cleavage and thicken down-section. These beds also contain abundant ilmenite. The Upper Beds or "coticule/manganese" beds contain slate, argillite, and garnet-quartz cotocule horizons (Ryan, 1994). This upper unit contains three distinct lithologies ranging from silty slate to fine sandstone (Mn-rich?) beds. The lower portion of the unit consists of medium- to darkgrey silty slate with well-developed cleavage and abundant pyrrhotite. Rare Mn-rich silt beds appear up-section. The lithology of the middle sequence includes abundant Mn-rich silt beds with little or no cleavage development and very silty slate beds with well developed slatey and/or spaced cleavage. The top sequence is a narrow package of sulphiderich sandy $\mathrm{Mn}$-rich beds and also includes numerous tightly folded (cm scale) beds containing abundant spessartine garnet and pyrrhotite.

Within the Rawdon Syncline the Halifax Formation is divisible into three units informally referred to as the "Rawdona", "Rawdon-b" , and Glen Brook units (Horne, 1995). The Rawdon-a subunit consists of black, locally graphitic slate and minor interbedded metasandstone. The black slate is locally sulphide-rich, and contains coarse disseminated pyrite, massive pyrite veins, and disseminated pyrrhotite. Pyrrhotite is typically elongate parallel to cleavage. The Rawdon-b subunit consists of medium to dark grey to black slate with little or no visible sulphide. It occurs at the gradational contact between the Rawdon-a subunit and the overlying Glen Brook unit. The Glen Brook unit consists of predominantly greengrey slate with very minor metasandstone. The slate has a very characteristic "banded" appearance defined by alternating light and dark, centimetre-scale beds. A notable feature of the Glen Brook unit is its uniform appearance throughout the entire sequence (Horne, 1995).

\section{Magnetic mineralogy}

\section{General}

Magnetite is the predominant magnetic mineral documented within the Goldenville Formation. Stern and Henderson (1983) performed X-ray diffraction on heavy mineral separates and determined the principle magnetic phase in the Goldenville Formation to be magnetite $\left(\mathrm{Fe}_{3} \mathrm{O}_{4}\right)$ with traces of hematite $\left(\mathrm{Fe}_{2} \mathrm{O}_{3}\right)$. The distribution of magnetite is heterogeneous with only a few coarse grained arenite horizons containing more than 2 to $3 \%$ magnetite by volume. Binney et al. (1986) noted numerous sulphide and oxide phases in drill core from stratigraphic horizons within the boundary between the Goldenville and Halifax formations which could also influence the magnetic character of the rock. These minerals included pyrrhotite, ilmenite, arsenopyrite, and pyrite. Schwarz and McGrath (1974), using thermomagnetic experiments, concluded that the predominant magnetic mineral in slate of the Halifax Formation is ferrimagnetic pyrrhotite $\left(\mathrm{Fe}_{7} \mathrm{~S}_{8}\right)$ but noted the presence of hexagonal pyrrhotite $\left(\mathrm{Fe}_{9} \mathrm{~S}_{10}\right)$. Cameron and Hood (1975) also identified up to 5\% pyrrho- 


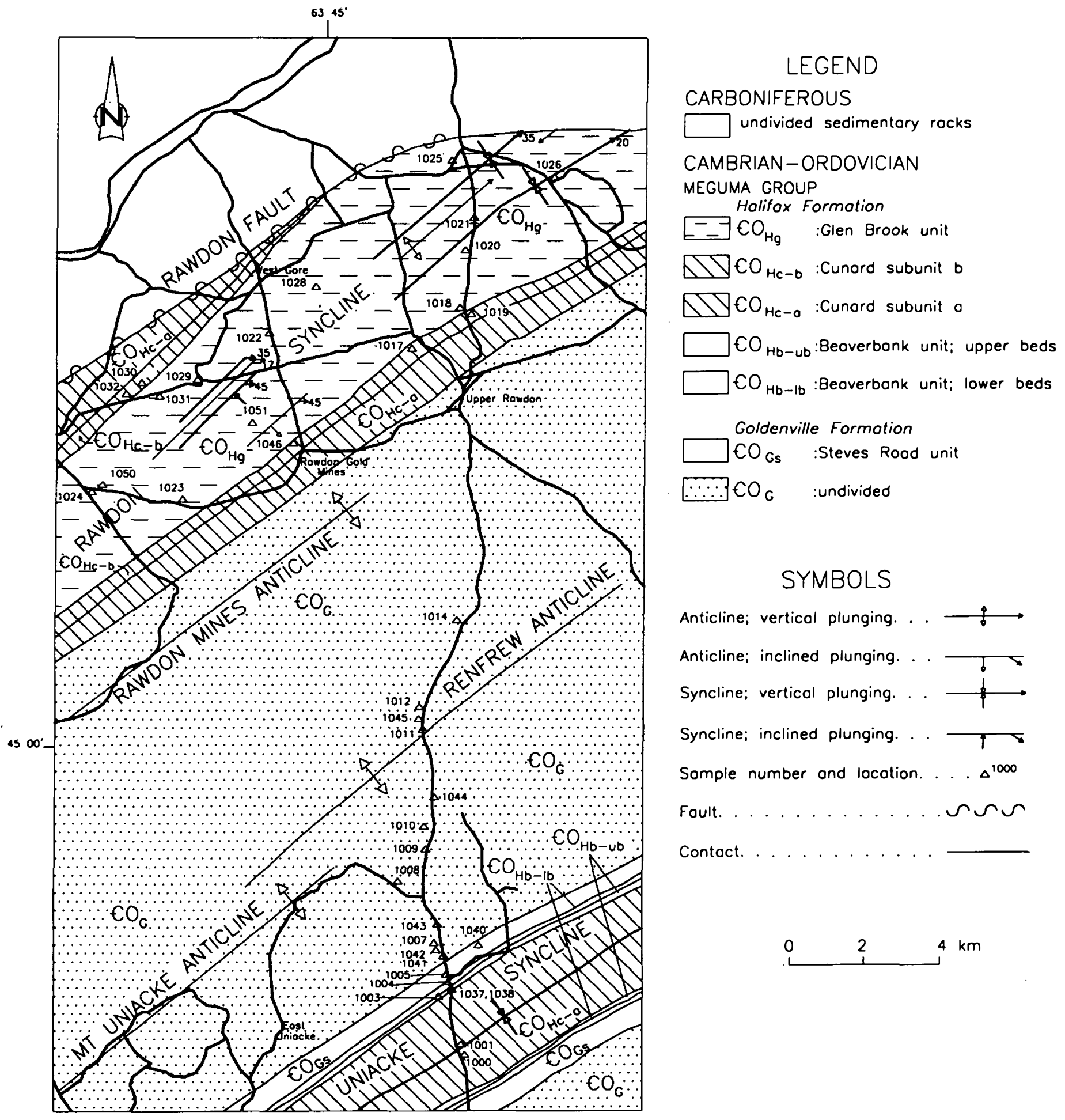

Fig. 3. Detailed geological map of the study area. Geology from Horne (1995) and Ryan (1994).

tite (by volume) in the Halifax Formation. In a study of samples from the Central Meguma area, King (1995) identified magnetite from trace amounts to more than $1.6 \%$ by weight in several samples. Pyrrhotite, in both hexagonal and monoclinic forms, was also found in numerous samples ranging from 0.02 to $3.20 \%$ by weight. Ilmenite was documented as occurring in fine needles comprising up to $5 \%$ by volume in several samples. This study also identified other magnetic minerals, including paramagnetic phyllosilicates such as chlorite and bi- otite. It was noted that in many instances these minerals comprise more than $60 \%$ of the sample volume.

\section{Detailed magnetic mineralogy}

The undivided Goldenville Formation is characterized by thickly bedded metasandstone and the primary magnetic minerals are locally abundant magnetite with traces of hematite and pyrite. The overlying Steves Road unit has a bi- 
modal magnetic mineralogy related to the interbedded slate and metasandstone. Slate samples contain abundant pyrrhotite and pyrite with minor hematite whereas samples of metasandstone contain magnetite and trace amounts of pyrite.

The transition between the Goldenville and Halifax formations is marked by two distinct stratigraphic units (Ryan, 1994), and within these units there appears to be systematic magnetic mineral variation from top to bottom. The Lower beds $\left(\mathrm{GHT}_{\mathrm{lb}}\right)$ contain abundant ilmenite whereas samples from the lowest section of the Upper Beds contain abundant pyrite. The top section of the Upper Beds contain abundant pyrrhotite and pyrite with locally abundant ilmenite.

The basal unit of the Halifax Formation, informally referred to as the Rawdon-a subunit (Horne, 1995), has a complicated magnetic mineral assemblage, in part due to the abundance of paramagnetic minerals. The black pyritiferous slates contain abundant pyrrhotite $\left(\mathrm{Fe}_{7} \mathrm{~S}_{8}\right.$ and $\left.\mathrm{Fe}_{9} \mathrm{~S}_{10}\right)$, pyrite, biotite, chlorite and minor ilmenite. Overlying the Rawdona subunit is the Rawdon-b subunit which is characterized by black to dark grey sulphide-poor slates (Horne, 1995). Magnetic mineralogy of this subunit is characterized by abundant ilmenite, rutile, and chlorite with trace amounts of pyrite. The green-grey slates (metasiltstones?) of the Glen Brook unit (Horne, 1993) contain few or no visible sulphide minerals and only trace amounts of iron oxides, predominantly in the form of hematite. Magnetic minerals in the Glen Brook unit which may affect the magnetic character of an outcrop include abundant ilmenite, biotite, and chlorite.

\section{MAgnetic SUSCEPTIBILITY}

\section{Field theory}

Factors affecting the magnetic susceptibility of an outcrop include magnetic mineralogy (quantity and type), grain size, crystal and/or grain orientation, and weathering. Weathering decreases the susceptibility of an outcrop by oxidizing ferrimagnetic minerals, but increasing grain size or quantity of magnetic minerals will increase susceptibility readings. When the quantity and type of magnetic minerals have been established it is possible to develop linear relationships between magnetic susceptibility and magnetic mineral content. Several authors have described the relationship, for magnetite-bearing samples, as a simple linear equation (Parasnis, 1972; Grant and West, 1965), relating magnetic mineral content (i.e., wt. \%) to magnetic susceptibility. King (1995) established similar equations for both the Goldenville and Halifax formations which are based on the presence of magnetite and pyrrhotite, respectively. These equations also include a factor related to the susceptibility contribution from accessory paramagnetic minerals.

\section{Data acquisition}

The operating principle of the portable susceptibility meter used in this study relies upon an electromagnetic signal generated by a hand-held meter. This controlled-frequency electromagnetic signal is first measured in free space and then next to the outcrop or sample. The frequency difference is directly proportional to the susceptibility of the sample. The susceptibility is then corrected for sample geometry (e.g., surface irregularities and sample size) to determine a true susceptibility. Field measurements were carried out using the Exploranium KT-5 hand-held susceptibility meter with a sensitivity of $1 \times 10^{-5}$ SI units and a range up to $999 \times 10^{-3}$ SI units. Each reading reflects the susceptibility of approximately $452 \mathrm{~cm}^{3}$ of outcrop (i.e., a hemisphere with a radius of $6 \mathrm{~cm}$ ). Between ten and twelve reading were taken per metre of outcrop, depending on the nature of the outcrop. Large lithologically homogeneous outcrops, which generally yielded a small range in susceptibility values, were sampled less intensively than lithologically heterogeneous outcrops (e.g., thinly bedded slate and metasiltstone) where a greater range in susceptibility values was more common.

During the acquisition of the susceptibility data some amount of compensation was required for factors other than mineralogy and lithology to ensure the best possible stratigraphic correlation. One such consideration was the anisotropy of magnetic susceptibility (AMS), due to the strong alignment of magnetic grains in some stratigraphic packages. This feature covers mainly the slates of the Halifax Formation where large pyrrhotite grains are aligned parallel to cleavage. Therefore, some care was taken to measure the minimum, intermediate, and maximum $k$ values of an outcrop by taking measurements parallel and perpendicular to bedding and/or cleavage. By noting the orientation of the susceptibility meter with respect to the outcrop and performing oriented measurements, an average susceptibility value, fairly representative of the bulk susceptibility, could be determined.

Weathering also affects in situ susceptibility data acquisition by reducing the amount of magnetic minerals within the volume of rock samples. Hence measurements were made on fresh surfaces where possible and the amount of weathering was recorded in field notes. Obviously there is some stratigraphic dependance on the degree of weathering for a particular outcrop. Therefore, statistical variations which may affect the calculation of the mean should be inherently related somewhat to stratigraphy.

\section{Data analysis}

More than three thousand susceptibility readings were collected in coordination with detailed geological mapping by the Nova Scotia Department of Natural Resources. The readings were assigned to the map units identified in Figure 3. Preliminary analysis involved preparing histograms for each major unit in order to assess the distribution of data and to identify any sub-populations that had stratigraphic correlatives (Fig. 5). Simple statistics (i.e., mean and standard deviation) were calculated for each population. The arithmetic mean was calculated and the standard deviation was also calculated to provide a measure of the variability that may be expected when recording in situ magnetic susceptibility. Table 1 contains the complete statistics for each of the units recognized in the study area. 
Table 1. Simple descriptive statistics for in situ susceptibility measurements.

\begin{tabular}{||c|l|c|c|c|c|c||}
\hline \multirow{2}{*}{ Formation } & \multicolumn{1}{|c|}{ Lithological Unit } & N & $\begin{array}{c}\text { Min. } \\
\mathbf{k}\end{array}$ & $\begin{array}{c}\text { Max. } \\
\mathbf{k}\end{array}$ & Std. Dev. & Mean k \\
\hline \multirow{5}{*}{ Carboniferous } & undivided Carboniferous & 153 & 0.01 & 0.56 & 0.098 & 0.17 \\
\hline \multirow{5}{*}{ Halifax } & Glen Brook unit & 861 & 0.09 & 0.81 & 0.099 & 0.37 \\
\cline { 2 - 8 } & Rawdon b subunit & 322 & 0.10 & 1.83 & 0.189 & 0.42 \\
\cline { 2 - 8 } & Rawdon a subunit (sulphide-poor) & 272 & 0.03 & 0.60 & 0.128 & 0.27 \\
\cline { 2 - 8 } & Rawdon a subunit (sulphide-rich) & 80 & 0.64 & 3.07 & 0.610 & 1.42 \\
\hline \multirow{5}{*}{ GHT zone } & Upper Beds (sulphide lamina) & 54 & 1.32 & 2.94 & 0.767 & 1.68 \\
\cline { 2 - 8 } & Upper Beds (Mn-rich beds) & 127 & 0.81 & 1.30 & 0.120 & 1.02 \\
\cline { 2 - 8 } & Upper Beds (silt beds) & 115 & 0.18 & 0.80 & 0.156 & 0.58 \\
\cline { 2 - 8 } & Lower-beds & 623 & 0.15 & 2.19 & 0.199 & 0.46 \\
\hline \multirow{5}{*}{ Goldenville } & Steve's Rd. unit (slate beds) & 152 & 0.30 & 0.67 & 0.091 & 0.41 \\
\cline { 2 - 8 } & Steve's Rd. unit (metasandstones) & 418 & 0.03 & 0.29 & 0.063 & 0.15 \\
\cline { 2 - 8 } & undivided Goldenville & 133 & 0.01 & 0.43 & 0.086 & 0.11 \\
\hline
\end{tabular}

\section{Results}

\section{Lithological correlations}

In the past, several authors have noted correlations between magnetic minerals and stratigraphy (Stern and Henderson, 1983; Schwarz and McGrath, 1974; Haysom et al., 1997). However analysis of the susceptibility data from the study area provides a more quantitative link between magnetic character and stratigraphy (Fig. 4).

Histograms of susceptibility values for the geological units (Fig. 5) show both normal and skewed distributions. Large values of skew correlate to populations with low mean susceptibility $(>0.25)$, such as the Carboniferous strata, the Goldenville Formation and the Steves Road unit. For those distributions the large skew is a result of the mean of a nonnegative population, occurring near zero (e.g., $k_{\mathrm{ave}}<0.25 \mathrm{x}$ $10^{-3} \mathrm{SI}$ ). Several of the major populations defined by the gross geology were readily divisible into normally distributed "sub-populations" which correlate with lithological variations in a particular map unit (Fig. 4). These sub-populations were identified in a single histogram for the whole unit (Fig. 4) and statistics on these smaller groups defined by mapping also indicate individual populations.

Figure 4 provides a simplified comparison of the mean susceptibility and variability of in situ measurements for the stratigraphic units and their respective lithologies occurring in the study area. Based on the mean susceptibility, distinct susceptibility values correspond to each unit and unique susceptibility values within each unit correspond to the predominant lithological characteristics. Overlap occurs in several populations (e.g., \pm one standard deviation), but the mean still provides a sensitive indicator of the lithologies that characterize each unit.

The Upper Beds of the GHT contain three populations (Figs. 4,5 ) that correspond to three distinct lithologies identified in the field and described by Ryan (1994). The first population is normally distributed around a susceptibility of $0.6 \mathrm{x}$ $10^{-3} \mathrm{SI}$, whereas the second population is roughly centered around a susceptibility of $1.0 \times 10^{-3} \mathrm{SI}$. The third group has a widely distributed population around a mean value of 1.7 $x 10^{-3} \mathrm{SI}$. The variability within this third population is due to the concentration of magnetic minerals into $\mathrm{cm}$-scale discrete horizons.

The Goldenville Formation is divided into two units in the study area (Fig. 3). The undivided unit consists mainly of thickly bedded metasandstone packages whereas the Steves Road unit consists of metasandstone packages interbedded with silt and slate horizons. The susceptibility of the metasandstone in both units is very similar and cannot be distinguished ( 0.11 versus $0.15 \times 10^{-3} \mathrm{SI}$ ); however, the slate in the Steves Road unit has higher susceptibility $(0.41 \mathrm{x}$ $10^{-3} \mathrm{SI}$ ). These slate values are superimposed in the population distribution (Fig. 5) and were recognized during the acquisition process.

The analysis of susceptibility data recorded in the transitional zone between the Goldenville and Halifax formations is characterized by a single major population for the 


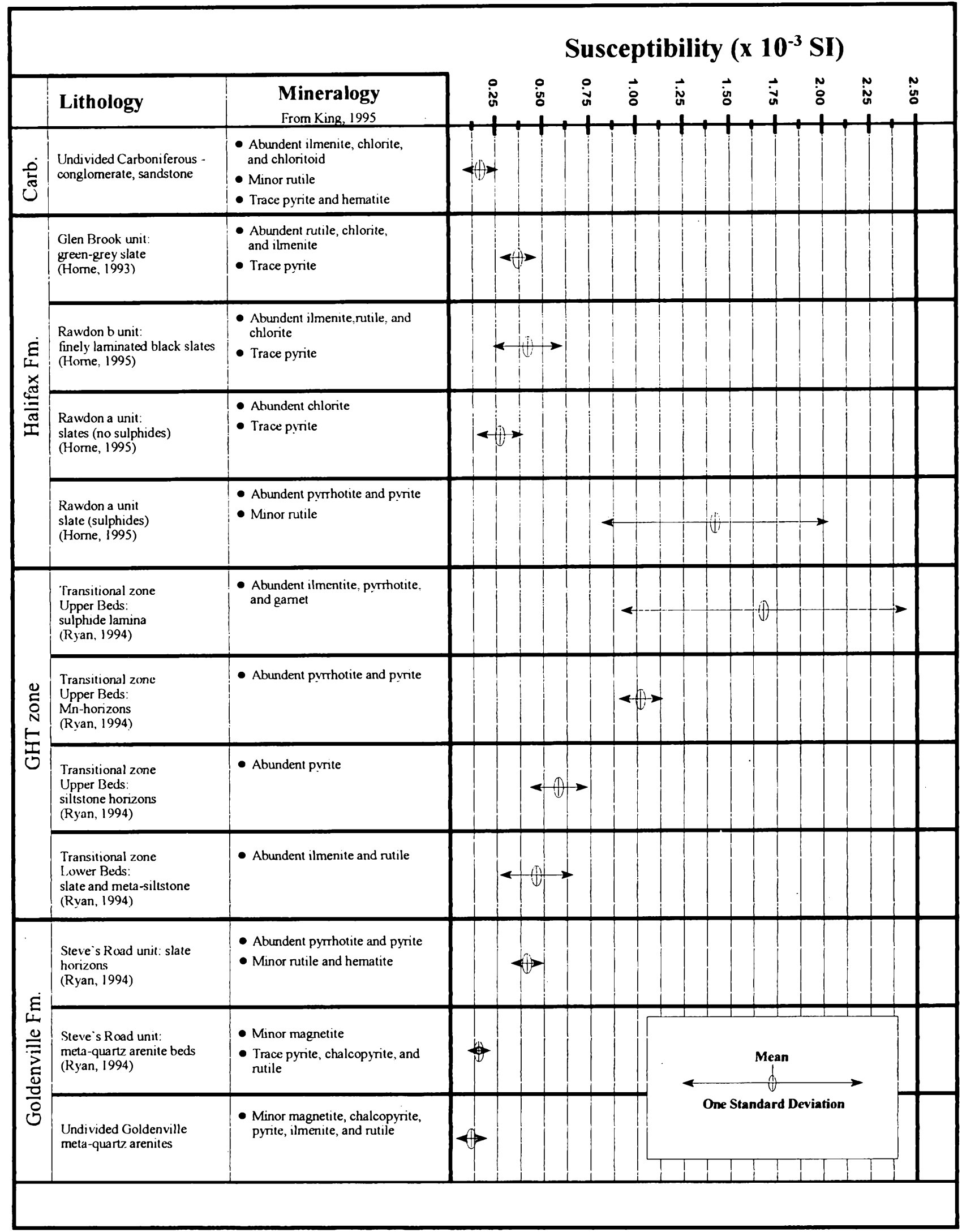

Fig. 4. A comparison of simple statistics on in situ susceptibility readings from the Central Meguma area. See Table 1 for data.

Lower Beds and three "sub-populations" for the Upper Beds (Figs. 4, 5). The top section of the Upper Beds ( 50-70 m thick) gave the most consistently high susceptibility read- ings in the study area. The moderately variable readings are centered around a high mean susceptibility $\left(1.68 \times 10^{-3}\right.$ SI) (Table 1). The variability is due to the small sample size 

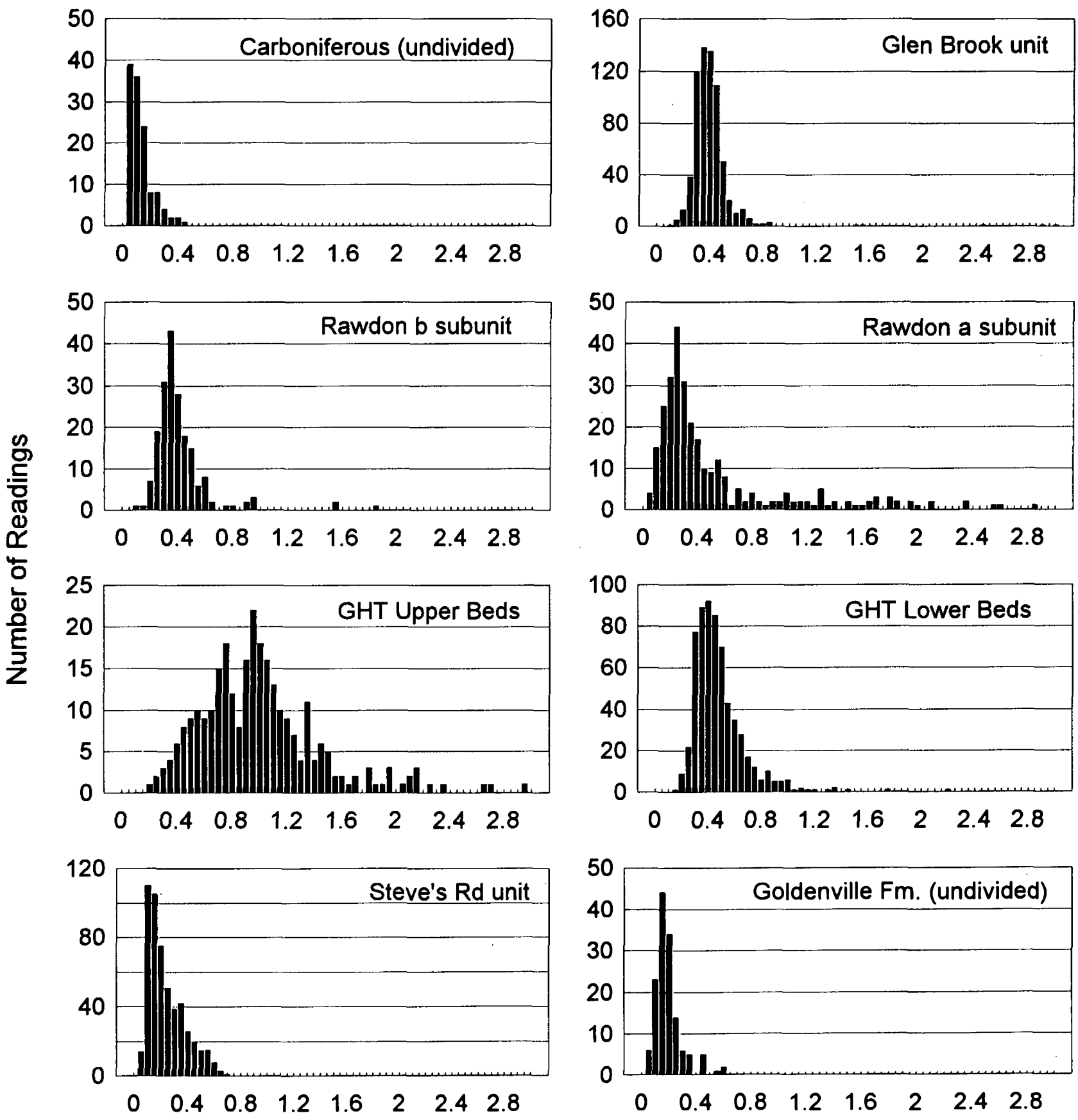

Susceptibility

Fig. 5. Histograms prepared for major stratigraphic units, as described by Horne (1995) and Ryan (1994), in the study area. All k values are $\times 10^{-3}$ SI units.

$(\mathrm{N}=54)$ and localized concentration of magnetic minerals. The middle strata of the Upper Beds have a well defined, high mean susceptibility (1.02 $\left.\times 10^{-3} \mathrm{SI}\right)$ exceeded only by the sulphide-rich Rawdon slate and the overlying Upper Beds. The high susceptibility is due to fine grained pyrrhotite. The lower $80 \mathrm{~m}$ of the Upper Beds are characterized by a moderate, relatively well defined mean susceptibility $(0.58$ $x 10^{-3} \mathrm{SI}$ ). Visually there does not appear to be any more sulphide than in other outcrops with more well developed cleavage; therefore, the slight $k$ increase may be the result of an overall increase in grain size. The Lower Beds of the transition zone have a more variable mean susceptibility of $0.46 \times 10^{-3} \mathrm{SI}$, which in comparison to the susceptibility of the overlying silty beds in the transition zone probably reflects a reduction in grain size.

Susceptibility measurements in the Halifax Formation slates were divided into four populations based on lithological and stratigraphic parameters. However, distribution histograms only reflect three populations corresponding to Rawdona subunit (slate), Rawdon-b subunit (sulphide-rich black slate), and Glen Brook unit (light green-grey slate). Susceptibility measurements for the Rawdon-a subunit were divided into 
two populations based on the presence of locally sulphiderich slate in contrast to more graphitic black slate containing no visible sulphide minerals. The $k$ values for the sulphidepoor beds are relatively closely centred around a mean of $0.27 \times 10^{-3} \mathrm{SI}$ which is markedly lower than the mean value for other slate packages in the Halifax Formation (i.e., Glen Brook unit, Fig. 4) which indicates a change in lithology and/or magnetic mineralogy. The sulphide-rich slate beds show some different characteristics, such as a higher mean susceptibility $\left(1.42 \times 10^{-3} \mathrm{SI}\right)$ and considerably more variability (Table 1, Fig. 4) than other slate units. The high susceptibility reflects the abundance of ferrimagnetic pyrrhotite and to a much lesser degree the presence of abundant paramagnetic pyrite. The large standard deviation is due to statistical and geological factors such as sample size $(\mathrm{N}=80$, Table 1), and oriented magnetic minerals. The heterogeneous distribution and strong alignment of the pyrrhotite grains along cleavage planes creates a strong AMS. This inherently affects the statistical distribution of the susceptibility data by creating a magnetic fabric consisting of maximum, intermediate, and minimum susceptibility axes (e.g., Housen and Van Der Pluum, 1991). The stronger the AMS the more range in susceptibility magnitudes and the larger the standard deviation within the whole population. The Rawdon-b subunit is a statistically non-distinct unit with variable in situ susceptibility values and a mean of $0.42 \mathrm{x}$ $10^{-3} \mathrm{SI}$. Several geological factors influencing these results include the physical discrimination of the geological units in the field. This unit marks the gradational conformable transition between the Rawdon-a subunit and the Glen Brook unit, hence, the field data undoubtedly include values from both these units where stratigraphic identification was not straightforward. In fact, the susceptibility probably lies somewhere in between the mean of the Rawdon-a subunit and the mean of the Glen Brook unit and the apparent ambiguity (Fig. 5) reflects the similar magnetic mineralogy present in all three units. The Glen Brook unit has a very consistent population centred around a well defined mean susceptibility of $0.37 \times 10^{-3} \mathrm{SI}$ which reflects the uniform character of the unit, as noted by Horne (1995). The magnetic response is due to the presence of abundant well-oriented paramagnetic minerals including ilmenite, chlorite, and chloritoid.

\section{Discussion}

\section{Lithology and stratigraphy}

Analysis of in situ magnetic susceptibility data has demonstrated a relationship between stratigraphy and magnetic susceptibility and established in situ susceptibility measurements as a useful mapping aid. Results from the central Meguma area of Nova Scotia suggest that magnetic susceptibility measurements are very sensitive indicators of lithological and mineralogical variations at the outcrop scale. All of the map units identified in the study area possess unique mean susceptibilities, although there is also overlap across units due to the large range in susceptibility readings. However, within map units distinct susceptibility populations also occur re- flecting lithological and/or mineralogical variation, and these relationships provide perhaps the most valuable tool for uniting aeromagnetic response with ground sources. With this type of information in hand, aeromagnetic maps, like those in Figure 2, provide far more useful geological information. An example of this type of correlation was provided by King (1994b), where susceptibility and aeromagnetic profiles were compared to a stratigraphic section through the GHT. The benefit of susceptibility mapping is primarily derived from the detail at which sampling is carried out. This allows individual beds to be delineated whereas the sampling (i.e., measurement) rate during a typical magnetic survey is obviously more coarse (15-50 $\mathrm{m}$ ) and tends to reflect the magnetic character of packages of strata at the tens-of-metres scale (King, 1994b).

\section{Sulphide content}

Another particularly useful application of in situ susceptibility measurements is determining the presence of sulphide minerals in outcrop. The excavation of sulphide-rich slate beds has been identified as a cause of acid drainage (Lund, 1987) and the heterogeneous distribution of sulphides requires a careful sampling procedure in order to locate sulphidemineralized beds. Within the Halifax Formation in particular, magnetic susceptibility tends to reflect the presence of both ferrimagnetic and paramagnetic minerals. High magnetic susceptibility readings are indicative of increased pyrrhotite and/or substantial amounts of pyrite, thereby providing a reliable method of delineating problematic, sulphide-enriched horizons. This relationship also establishes another use for enhanced aeromagnetic maps in urban planning and development by presenting a detailed regional view of problematic strata, thus helping to avoid the excavation of such strata which can lead to irreversible acid drainage such as that documented at the Halifax International Airport (Lund, 1987).

\section{Magnetic fabrics and aeromagnetic interpretation}

The original goal of this project was the ground followup of aeromagnetic anomalies in the Meguma Group. Susceptibility mapping proved extremely successful in locating anomalous horizons within monotonous, thickly bedded metagreywacke packages and allowed for correlation along several kilometres of strike length. In situ susceptibility data were also found to be sensitive to magnetic fabrics, and field measurements taken orthogonal to bedding and/or cleavage provided a rudimentary indicator of AMS. This feature has applications for the interpretation of magnetic data where magnetic anomalies have relative amplitudes not indicative of the known mineralogy. Regionally, such is the case for anomalies in the Goldenville Formation where, during other field investigations by the author, several aeromagnetic anomalies were ground-proofed and found to have magnetic susceptibility values more than a full order of magnitude higher than in situ susceptibilities from pyrrhotite bearing slates. However, aeromagnetic anomalies over the Goldenville Formation are rarely more than 
half the amplitude of anomalies over the Halifax Formation. This is interpreted to represent the enhancement of the magnetic field within the slate units by the strong, preferential orientation of pyrrhotite crystals and the magnetic fabric developed by the paramagnetic phyllosilicates.

\section{ACKNOWLEDGEMENTS}

I am thankful for the field support provided by the Nova Scotia Department of Natural Resources, in particular field time with Bob Ryan and Rick Horne. This paper benefited from an early review by Rick Horne which allowed the structure and results to be more compatible with other work concerning the Central Meguma area. The many days in the field with Rick provided me with geological information that was key in resolving some very interesting geophysical problems. I thank members of the Nova Scotia Department of Natural Resources who had the foresight to realize that proper interpretation of geophysical data requires a great deal of basic research and for providing me with the opportunity to complete some of it. Much of this work was funded by the Canada-Nova Scotia Agreement on Mineral Development (1992-1995).

BALL, F.D. 1974. Sulphide transformation and magnetic expression of a thermally metamorphosed contact aureole in the Goldenville Formation, Nova Scotia. M.Sc. thesis, University of New Brunswick, Fredericton, 101 p.

Binney, W.P., Jenner, K.A., SANGster, A.L., and Zentilli, M. 1986. A stratabound zinc-lead deposit in Meguma Group metasediments at Eastville, Nova Scotia. Maritime Sediments and Atlantic Geology, 22, pp. 65-88.

Borradalle, G. and Sarvas P. 1990. Magnetic susceptibility fabrics in slates: structural, mineralogical and lithological influences. Tectonophysics, 172, pp. 215-222.

Cameron, G.W. and Hood, P.J. 1975. Residual aeromagnetic anomalies associated with the Meguma Group of Nova Scotia and their relationship to gold mineralization. Geological Survey of Canada Paper 75-1C, pp. 197-211.

Fletcher, H. and Faribault, E.R. 1911. Southeast Nova Scotia. Canada Department of Mines, Geological Survey Map 53a, scale $1: 250,000$.

Grant, F.S. and West, G.F. 1965. Interpretation theory in applied geophysics. McGraw-Hill Book Company.

Graves, M.C. and Zentilli, M. 1988. Geochemical characterization of the Goldenville-Halifax transition zone of the Meguma Group, Nova Scotia. Nova Scotia Department of Mines and Energy Report 87-5.

Haysom, S.J., HoRne, R.J., and Pe-Piper, G. 1997. The opaque mineralogy of metasedimentary rocks of the Meguma Group, Beaverbank-Rawdon area, Nova Scotia. Atlantic Geology, 33, pp. 105-120.

HoRne, R.J. 1993. Preliminary report on the geology of the Rawdon area. In Mines and Mineral Branch, Report of Activities 1992. Edited by D.R. MacDonald and K.A. Mills. Nova Scotia Department of Natural Resources, Mines and Energy Branches Report 93-1, pp. 61-67.

-.-- 1995. Update on geological mapping of the Rawdon Hills and Renfrew Gold District, Central Meguma Mapping Project. In Program and Summaries, Nineteenth Annual Review of Activities. Edited by D.R. MacDonald and K.A. Mills. Nova
Scotia Department of Natural Resources, Minerals and Energy Branch, Report 95-2 p. 9.

Housen, B.A. and Van Der Pluum, B.A. 1991. Slatey cleavage development and magnetic anisotropy fabrics. Journal of Geophysical Research, 96, B6, pp. 9937-9946.

KePPIR, J.D. 1979. Geological Map of Nova Scotia. Nova Scotia Department of Mines and Energy map, scale 1:500,000.

KING, M.S. 1994a. Magnetic mineralogy and susceptibility of the north-central Meguma Group: Implications for the interpretation of aeromagnetic total field, first derivative and second derivative. Nova Scotia Department of Natural Resources, Open File Report 94-004.

...- 1994b. Magnetic signature of the Goldenville-Halifax transition zone: North Beaverbank. Nova Scotia Department of Natural Resources, Open File Report 94-015.

.-.- 1995. Interpretation of magnetic data from the Meguma Group of Nova Scotia: magnetic mineralogy. In Minerals and Energy Branch, Report of activities 1994. Edited by D.R. MacDonald and K.A. Mills. Nova Scotia Department of Natural Resources, Minerals and Energy Report, 95-1, pp. 63-72.

LuND, O.P. 1987. Acid drainage from mineralized slate at Halifax airport. In Proceedings, Acid Mine Drainage Seminar/Workshop, Halifax, Nova Scotia, March 23-26, 1987, p. 137.

Nagata, T. 1961. Rock Magnetism. Maruzen Company Limited, Tokyo, 350 p.

O'Brien, B.H. 1988. A study of the Meguma Terrane in Lunenburg County, Nova Scotia. Geological Survey of Canada, Open File 1828,80 p.

Parasnis, D.S. 1972. Principles of applied geophysics. Chapman and Hall, London, p. 6.

Ryan, R.J. 1994. Preliminary investigations of Meguma Group stratigraphy in the Beaverbank area, Nova Scotia. In Mines and Minerals Branch, Report of Activities 1993. Edited by D.R. MacDonald. Nova Scotia Department of Natural Resources, Mines and Energy Branches Report, 94-1, pp. 137 140.

Schenk, P.E. 1970. Regional variation of the flysch-like Meguma Group (Lower Paleozoic) of Nova Scotia, compared to recent sedimentation off the Scotian Shelf. Geological Association of Canada, Special Paper 7, pp. 127-153.

....- 1991. Events and sea-level changes on Gondwana's margin: The Meguma Zone (Cambrian to Devonian) of Nova Scotia, Canada. Geological Society of America Bulletin, 103, pp. 512-521.

Schwarz, E.J. and McGrath, P.H. 1974. Aeromagnetic anomalies related to pyrrhotite occurrences in the Canadian Appalachian Region. Geological Survey of Canada Paper 741, B, Current Research, pp. 107-108.

Sharma, P.V. 1986. Geophysical methods in geology, second edition. Elsevier Scientific Publishing Company, New York.

Stern, R.A. and Henderson, J.R. 1983. Observations on the nature and origin of magnetic total field and vertical gradient anomalies over the Goldenville Formation in Nova Scotia. Geological Survey of Canada Paper 83-1, B, Current Research, pp. 92-101.

TAYLOR, F.C. and SCHILLER, E.A. 1966. Metamorphism of the Meguma Group of Nova Scotia. In Canadian Journal of Earth Sciences, 3(7), pp. 959-974.

WALDRON, J.W.F. 1991. The Goldenville-Halifax transition, Mahone Bay, Nova Scotia: relative sea-level rise in the Meguma source terrane. In Canadian Journal Earth Sciences, 29, pp. 10911105 . 